\title{
Prospects for Oil and Gas in Zimbabwe, Zambia and Botswana
}

\author{
by K.-U. Reimann
}

Recent geological and geophysical studies of the Karoo and pre-Karoo rifts and basins of Zimbabwe, Zambia, and Botswana have focussed on the thick sedimentary sequences overlying the crystalline basement. This review of the work of a West German team in cooperation with local geological surveys confirms the presence of potential hydrocarbon source rocks in all the areas reported here. Most have passed through the "oil window" and are now in the stage of wet gas generation; favourable traps also exist. The author evaluates each basin and trough for its hydrocarbon potential. (Ed.)

\section{Introduction}

In the past decade, hydrocarbons have been found in various parts of Africa that are structurally characterized by a cratonic environment and rift tectonics (Chad, Sudan and Niger). These oil and gas discoveries demonstrate that favourable conditions for hydrocarbon generation exist in grabens of the region. This review is an attempt to evaluate the possibility of hydrocarbons in geologically similar rifts and block-faulted basins in three landlocked countries that must import all the liquid fuels needed for their daily consumption - Botswana, Zambia and Zimbabwe (Fig. 1). Despite previous exploration efforts, no exploratory drilling for hydrocarbons has been carried out in any of these countries.

The present evaluation is based on data obtained from geological, aeromagnetic, geo-electric and gravity surveys, as well as from the interpretation of Landsat imagery and $\log$ records of numerous wells drilled in the course of coal exploration (e.g. Reeves and Hutchins, 1976; Coates et al., 1979; Pretorius, 1979; Saviaro, 1979; Mallick et al., 1981; Money, 1981; Tankard et al., 1982; Paroda, 1983; Smith, 1984; Zhou, 1984).

\section{General Geological Setting}

The African continent is the result of at least seven major orogenic events (Clifford in Clifford and Gass, 1970). Its structural development was initiated by an orogeny represented by the greenstone belt in the Barberton Mountain Land of the Transvaal, which has an age of about 3,400 $\mathrm{Ma}$ (Viljoen and Viljoen, in Clifford and Gass, 1970). The main part of the present African craton was finally shaped by early Palaeozoic times. Orogenesis afterwards was confined to peripheral regions such as Mauritania, the middle Palaeozoic to early Mesozoic Cape Fold Belt, and the Atlas Mountains of Alpine age. After consolidation of the orogenic belts, the entire region was dominated by a cratonic environment, with epeirogenic movements continuing to the present. The basins and troughs formed by warping and rifting served as depositional centers for glacial, fluvioglacial, fluviatile, lacustrine and aeolian sediments of the Karoo System (Supergroup - Ed.) of Carboniferous to Early Jurassic age and younger units.

For the most part these downwarped basins and rifted troughs were sites for widespread volcanism, particularly during Mesozoic times. In addition to dikes and sills, there were widely distributed lavas, some with sedimentary intercalations. In the Cenozoic, the predominant sediments were aeolian and fluviatile. These cover large areas of southern Africa, burying most of its Palaeozoic and Mesozoic rocks. In general, all the basins and troughs described here passed through a similar history from the late Palacozoic to the Recent. This applies both to the tectonic events and to the depositional history of Karoo and post-Karoo sediments.

Because of their structural heterogeneity, the orogenic belts were affected by warping and rifting lasting from late Palaeozoic to Recent, whereas the older cratonic nuclei resisted these tectonic stresses. As a result, all the haroo troughs lie within the orogenic belts surrounding the stable cores. Nevertheless, in detail the troughs are aligned along zones of crustal weakness, which may cross the structural trends of the orogenic belts (Drysdall and Weller, 1966). For example, the NE-SW part of the mid-Zambezi valley intersects at right angles Precambrian metasediments and the trend of metamorphic facies boundaries.

Data on the lithology, thicknesses and facies of the deposits in these rifts and basins come almost entirely from coal mines, boreholes and outcrops located at their margins and in gently downwarped depressions where $K$ aroo and postKaroo sediments unconformably overlie older rocks. Aeromagnetic and gravity surveys indicate a magnetic basement locally as deep as $15,000 \mathrm{~m}$, but the deepest parts of the troughs are poorly known.

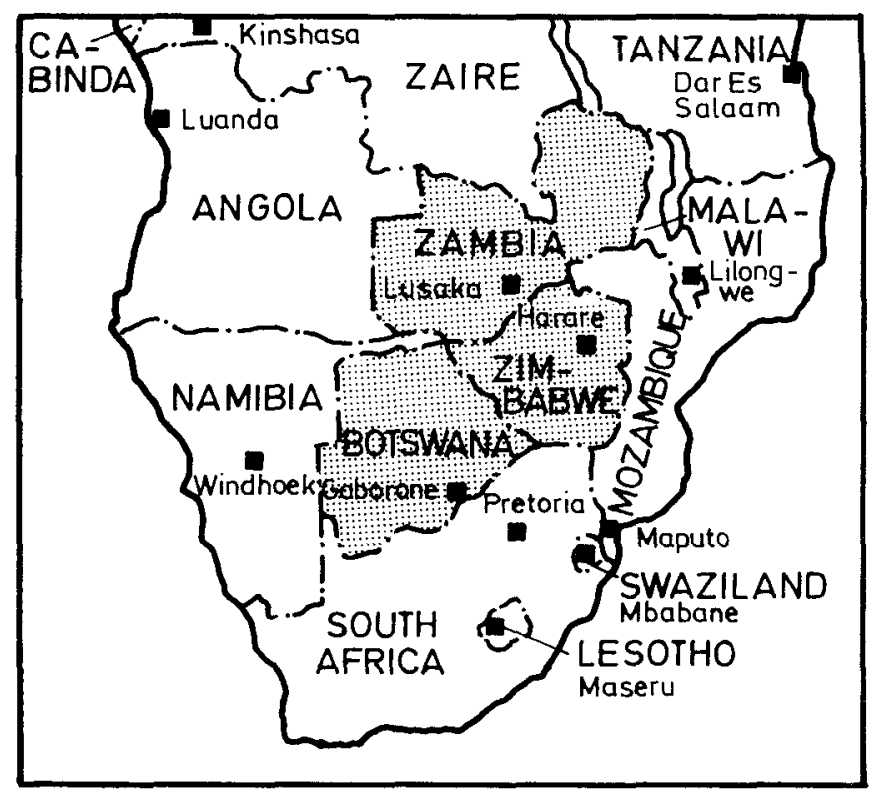

Figure 1: Southern Africa. Study area stippled 


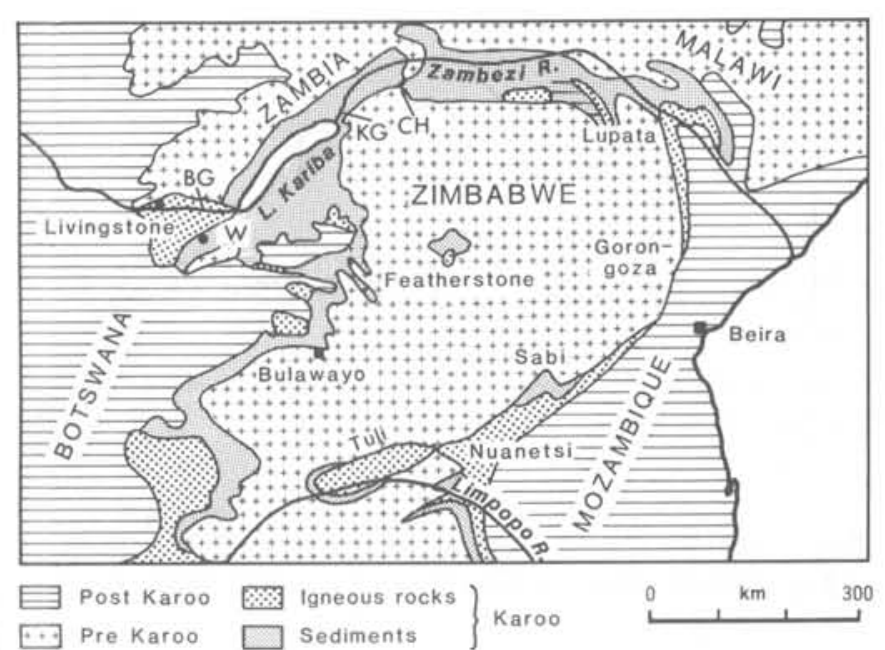

Figure 2: Distribution of Karoo rocks in the eastern part of the study area (modified after Cox, in Clifford and Gass, 1970). BG - Batoka Gorge, CH Chewore Horst, KG - Kariba Gorge, W - Wankie.

The Mid-Zambezi Valley: Stratigraphy and Structural Development

Of all the troughs in the region under discussion, the midZambezi Valley, which straddles the Zambia-Zimbabwe border, is the best known in terms of structure and stratigraphy. This $\mathrm{SW}$ to $\mathrm{NE}$ trending rift extending between the Batoka and Kariba Gorges (Fig. 2) will be used here to illustrate the general development of tectonic and deposition events in rifted structures in central southern Africa. The mid-Zambezi Valley is a markedly asymmetrical rift, with its steeper slope on the northwestern side. It separates the Zimbabwe Shield in the south from the Choma-Kalomo granite to the north.

The topography on the pre-Karoo rocks here, as shown by drift hole data from coal exploration, is characterized by a mature relief ranging from an almost perfect peneplain to a slightly undulating relief, rising to approximately $150 \mathrm{~m}$. Sediments of glacial origin or affinity deposited during Dwyka times (Figs. 3 and 4) are common (Tavener-Smith, 1960) and rest unconformably on basement rocks. The patchy occurrence of tillites indicates that they were preserved merely in sheltered hollows (Drysdall and Weller, 1966), whereas most of this glacial material was re-worked and re-deposited by melt-water streams. Where they are preserved, the tillites are overlain by a sequence of coarse arenaceous sediments, composed mainly of conglomerates and conglomeratic sandstones with some intercalations of red feldspathic mudstone and varved siltstone layers, indicating deeper water.

According to Tavener-Smith (1960), the most characteristic horizon of the Lower Wankie Sandstone is at the top of this formation. It is a sandstone deposited in a lake, which probably resulted from the first linear downwarping in the area. Grain size as well as the thickness of this sandstone horizon increase northwestwards, indicating a near shoreline in that direction. Carbonaceous matter intercalated in the uppermost portion of this sandstone heralds a remarkable change in depositional environment, from the arenaceous Dwyka to the coal-shale Ecca environment.

In the Siankondobo area (see Fig. 9), Denman and Money (1968) described a break within a sandstone regarded as time-equivalent to the Lower Wankie. In some places this is an angular unconformity, in others a disconformity; it separates the Siankondobo Sandstone from the overlying Mamba Sandstone (Fig. 3). In contrast to previous workers,

\begin{tabular}{|c|c|c|c|c|c|c|}
\hline $\begin{array}{l}\text { European } \\
\text { Equivalents }\end{array}$ & \multicolumn{2}{|c|}{ System } & Series & Formation & $\begin{array}{c}\text { Thickness } \\
\text { in } \mathrm{m}\end{array}$ & $\begin{array}{l}\text { Litho- } \\
\text { logy }\end{array}$ \\
\hline $\begin{array}{c}\text { Lower } \\
\text { Jurassic }\end{array}$ & \multirow{7}{*}{$\begin{array}{l}0 \\
0 \\
\approx \\
< \\
x\end{array}$} & \multirow{3}{*}{$\frac{\frac{2}{6}}{\frac{10}{5}}$} & \multirow[b]{2}{*}{ STORMBERG } & \begin{tabular}{|l|} 
Batoka \\
Basalts \\
\end{tabular} & 300 & $\begin{array}{l}v^{v} v^{v} v^{v} v^{v} \\
y^{2} y^{2} y^{2} y\end{array}$ \\
\hline \multirow[t]{2}{*}{$\begin{array}{c}\text { Upper } \\
\text { Triassic }\end{array}$} & & & & $\begin{array}{l}\text { Red Sandstones } \\
\text { Sandstones } \\
\text { Interbedded } \\
\text { Mudstones }\end{array}$ & 1950 & \\
\hline & & & $\begin{array}{c}\text { UPPER } \\
\text { BEAUFORT }\end{array}$ & \begin{tabular}{|l|} 
Escarpment \\
Grit \\
\end{tabular} & 400 & \\
\hline $\begin{array}{l}\text { Upper } \\
\text { Permian }\end{array}$ & & \multirow{4}{*}{$\frac{2}{3}$} & $\begin{array}{c}\text { LOWER } \\
\text { BEAUFORT }\end{array}$ & $\begin{array}{l}\text { Madumabisa } \\
\text { Mudstone } \\
\text { Formation }\end{array}$ & 700 & \\
\hline \multirow[t]{2}{*}{$\begin{array}{l}\text { Lower } \\
\text { Permian }\end{array}$} & & & $\mathrm{ECCA}$ & $\begin{array}{l}\text { Gwembe Coal } \\
\text { Formation }\end{array}$ & 100 & \\
\hline & & & DWYKA & $\begin{array}{l}\text { Lower Wankie } \\
\text { Sandstone }\end{array}$ & 150 & $\Delta . \Delta$ \\
\hline Carboniferous & & & & Glacial Beds & & \\
\hline
\end{tabular}

\begin{tabular}{|c|c|c|c|}
\hline v v & Babalts & $\Delta$. & Tillite \\
\hline$E=-2$ & Mudstones & $\sim$ & Unconformity, disconformity \\
\hline 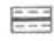 & Coal Seams in carbonaceous shales & UWS & Upper Wankie Sandstone \\
\hline 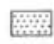 & Sandstones & MC & Main Coal Seam \\
\hline 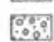 & & ss & $\begin{array}{l}\text { Mamba Sandstone } \\
\text { Siankondobo Sandstone }\end{array}$ \\
\hline
\end{tabular}

Figure 3: Karoo stratigraphy of the mid-Zambezi Valley, Gwembe district, Zambia.

who have placed the lower boundary of the Gwembe Coal Formation at the base of the Main Seam, Denman and Money placed this at the base of the Mamba Sandstone. This would coincide with the facial break in the upper portion of the Lower Wankie Sandştone.

The Gwembe Formation consists mainly of coal seams and carbonaceous mudstones. During this part of Early Permian time, the depositional environment was dominated by extensive swamps with an obviously denser vegetation along the gently inclined margins of the downwarped area. The commonly observed splitting of coal seams into thinner coal layers and carbonaceous mudstone horizons indicates local tectonic instability and discontinuous subsidence during deposition.

The Main Seam in the Wankie area ranges up to $12 \mathrm{~m}$ in thickness with an average of $9 \mathrm{~m}$ and provides evidence of a slow and more persistent subsidence during the time of

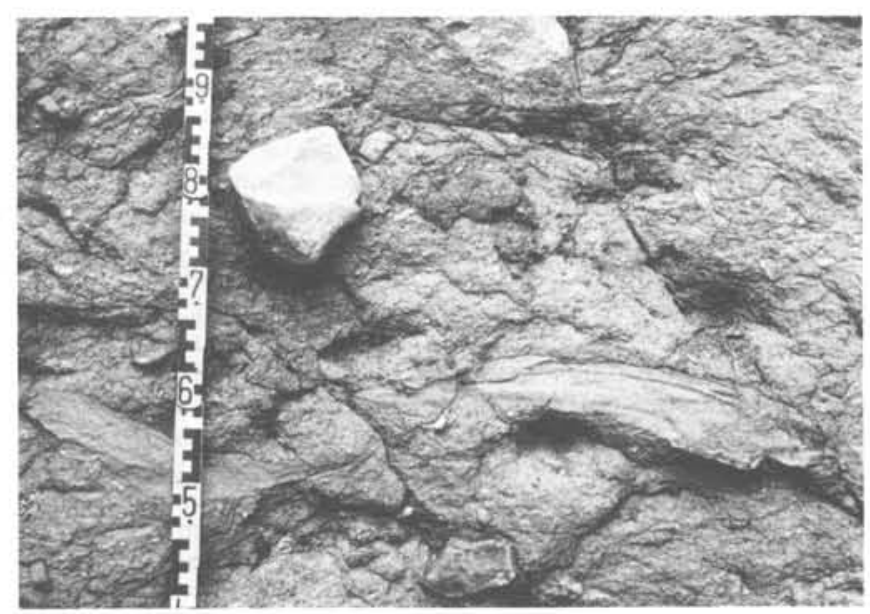

Figure 4: Dwyka tillite, east of Wankie, Zimbabwe. Scale in cms. Photo by D. Lepper. 
deposition (Watson, 1960). Similar conditions have prevailed in the Kandabwe and Mulungwa areas. Tectonic instability was obviously not restricted to these depositional centers. Five sandstone horizons observed in the Siankondobo area (Drysdall et al., 1967) have been attributed to minor movements in the northwestern source area. They represent five cycles in the Gwembe Coal, reflecting the spasmodic character of these locally restricted tectonic events during Lower Ecca times.

The Upper Wankie Sandstone at the top of the Gwembe Coal represents another tectonic movement, and the threshold of a new environmental development. This is marked by a change to lacustrine grey-green mudstones of the Madumabisa Mudstone. Drysdall and Weller (1966) pointed out that this change was diachronous, because the Madumabisa Lake existed in the southwestern part of the downwarp at the same time as coals and carbonaceous mudstones were being deposited in its northeastern portion. Generally, the lithology of the lower part of the Madumabisa Mudstone succession indicates a continuous lacustrine deposition resulting from a steady, gentle subsidence.

The middle portion of this $457-610-\mathrm{m}$ sequence is more varied in lithology. Sandstone horizons represent time intervals of increased tectonic activity, whereas limestone bands mark short phases of tectonic stability. Bituminous limestone horizons, rich in plant remains, indicate shallow water conditions and the presence of islands covered by a rich vegetation (Tavener-Smith, 1960).

After this time of shallow-water conditions, the basin subsided once more. Green and grey-green mudstones of the Upper Madumabisa Formation were deposited during that time, but no further subsidence occurred and the basin silted up. By the end of this period an equilibrium between the source and depositional areas had been reached, persisting until the next tectonic pulse in Late Triassic times (Tavener-Smith, 1960). There are still various opinions about the nature of the break between the Madumabisa Mudstone and the Escarpment Grit; some workers assume an unconformity, others a disconformity. Evidence of minor erosion has been found at the margins of the troughs.

The Escarpment Grit, a thick sequence composed of coarse, poorly sorted crystalline detritus, resulted from this tectonic event, which created a pronounced relief between the depositional area and the crystalline basement rocks in the neighbourhood (Fig. 5). This major movement along the transitional zone between the down- and upwarps was not local but rather was a regionally important event.

After deposition of the Escarpment Grit, the upwarping slowed gradually, resulting in the deposition of finer grained sandstones and mudstones of the Stormberg Series. A general trend prevailed to arid conditions, as evidenced by red mudstone horizons and dune-bedded sandstones at the top of the Stormberg sediment. Large parts of the subcontinent are covered by these aeolian sandstones.

Towards the close of Stormberg times, in the Early Jurassic, there was a spectacular outpouring of basaltic lavas throughout southern Africa. A large part of the study area, including the Lower Karoo depositional centers as well as the crystalline basement rocks of the former source areas, were covered by these Batoka Basalt flows (Fig. 6). Aeolian sandstones intercalated with the lower portion of these lavas indicate that the basalt did not extrude continuously (Tavener-Smith, 1960). The volcanic events also included the intrusion of dikes and sills, as indicated by recent aeromagnetic and gravity surveys.

After this Upper Karoo voleanism, the region was once more affected by major tectonic activities. Faulting was concentrated along the transitions between upwarps and downwarps and along old zones of crustal weakness. The Karoo troughs received their final shaping, and a new relief was formed. Soon after the slowing down of the tectonic

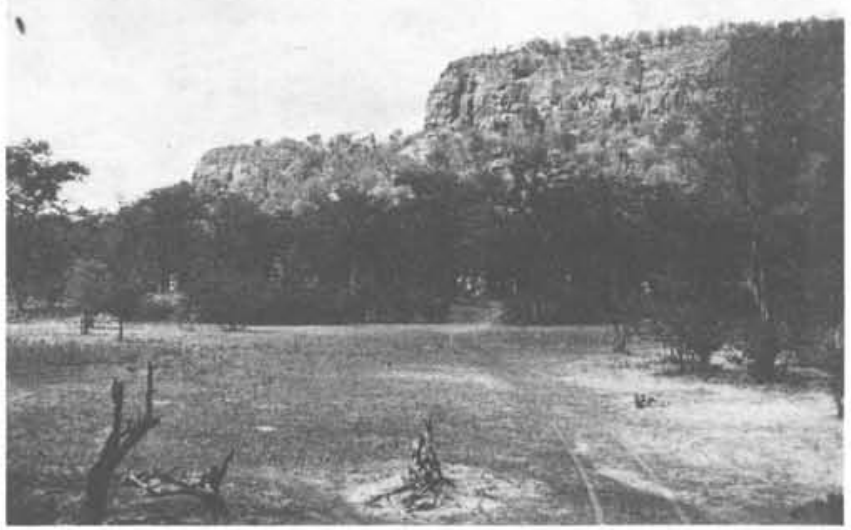

Figure 5: Cliff formed by the Escarpment Grit, which overlies fine-grained clastics of the Madumabisa Formation, east of Wankie, Zimbabwe. Photo by $D$. Lepper.

activities, the region underwent a peneplanation that lasts to this day. This process led to the accumulation of Cretaceous and younger sediments in some of the depressions.

\section{Oil and Gas Potential of the Mid-Zambezi Valley}

Although there is still a lack of information, particularly about the deeper portions of the mid-Zambezi Valley, the foregoing outline of its stratigraphic and structural development permits a first rough evaluation of its hydrocarbon possibilities. The Gwembe Formation and the lower portions of the Madumabisa Mudstone consist mainly of coal seams and carbonaceous mudstones (Fig. 7), guaranteeing a high total-organic content. Since the organic matter of these sediments is exclusively composed of phylogenetically higher developed land plants, this sequence has to be regarded as a possible source for generation of gas only (kerogen type III).

The middle portion of the Madumabisa Formation contains some horizons of "dark-coloured bituminous limestones containing abundant plant remains" (Tavener-Smith, 1960, p. 23). This description indicates that the organic matter of these sediments has also to be classified as type III kerogen,

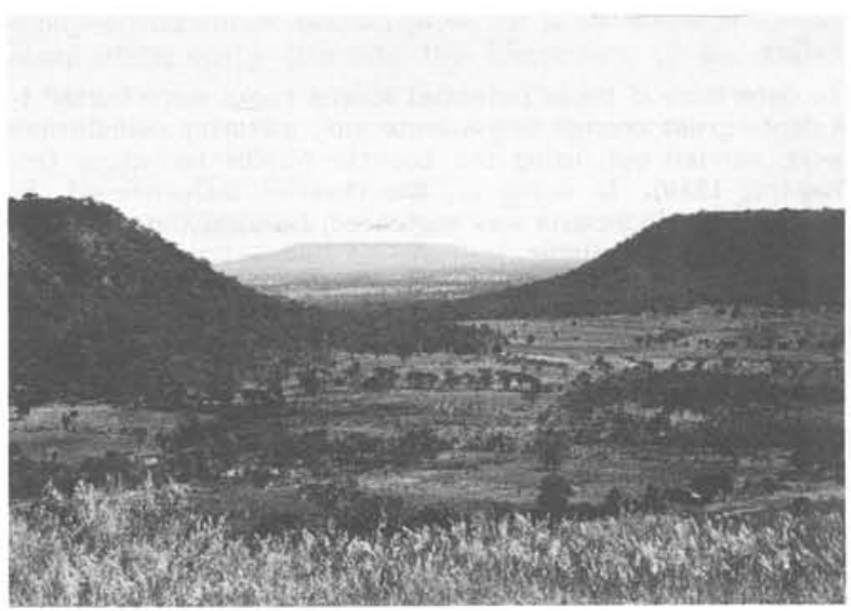

Figure 6: Typical Upper Karoo landscape. Fluviatile and aeolian sandstones with basalt at the top. Photo by $D$. Lepper. 


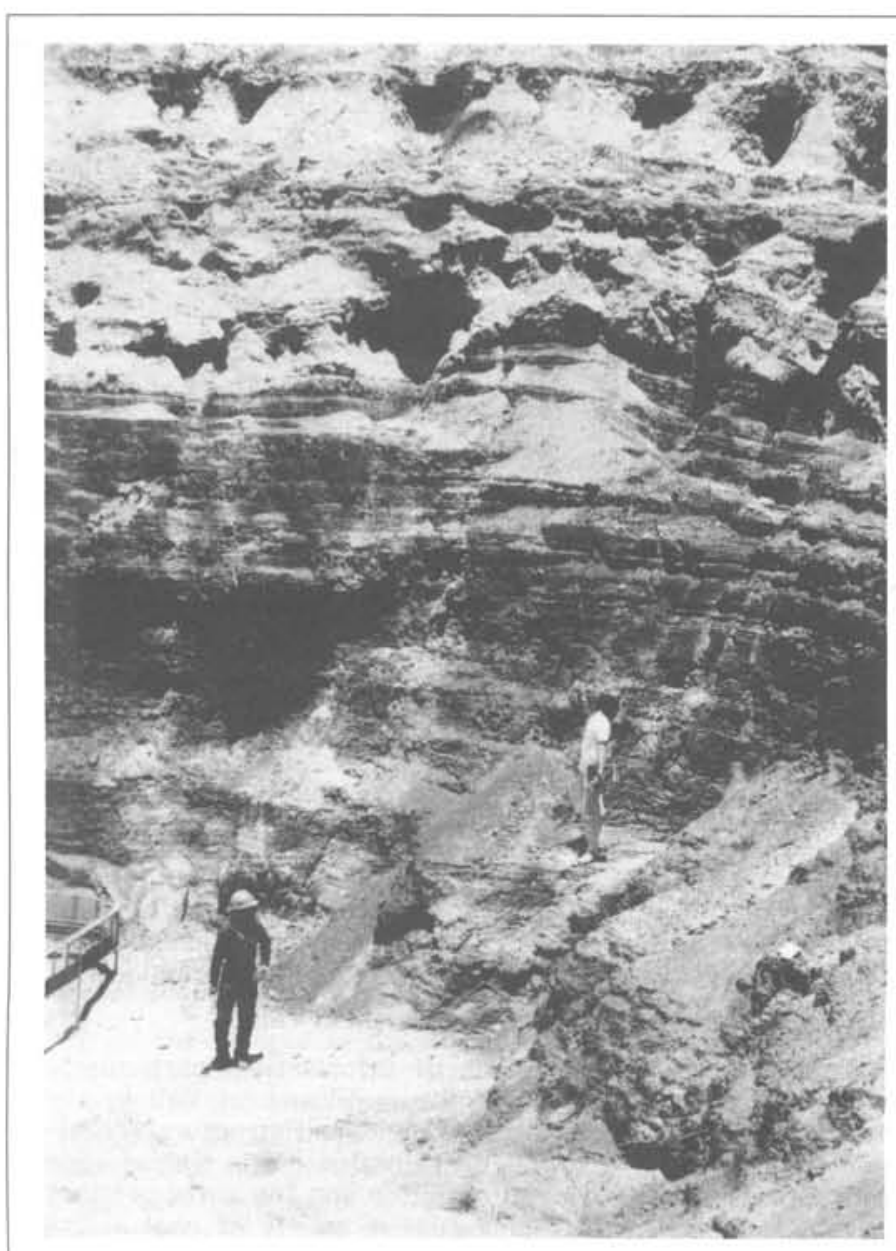

Figure 7: Alternation of coal seams and carbonaceous shales of the Bcca Series, Morupule Colliery, Botswana.

Because of their limited minor thickness and lateral extent of the limestone bands, this portion of the sequence cannot be considered as a potential source rock. There may, however, be a possibility of source rocks such as fine-grained, lacustrine clastics with algal remains that could contain type I kerogen, particularly in that part of the Madumabisa Mudstone deposited in the axial portion of the mid-Zambezi Valley.

To determine if these potential source rocks were buried to a depth great enough to generate gas, maturity ealculations were carried out, using the Lopatin-Waples technique (see Waples, 1980). In doing so, the thermal influence of the Lower Jurassic basalts was neglected, because the necessary data were not available.

Figure 8 shows the burial history and the process of maturation in terms of Lopatin's temperature-time index (TTI), assuming a gradient of $3^{\circ} \mathrm{C}$ per $100 \mathrm{~m}$ related to the base of the Gwembe Formation. The graph clearly illustrates that the base of the potential source rocks reached the stage of maturity for the onset of oil generation window by Late Triassic times and passed through it in the Late Jurassic. Since then, the source rocks have been in the zone of wet gas generation. If thermal gradients of $2.5^{\circ} \mathrm{C} / 100 \mathrm{~m}$ and $3.5^{\circ} \mathrm{C} / 100 \mathrm{~m}$ are used for the maturity calculation, the base of the Gwembe Coal would now be in the wide maturity range between the oil window and dry gas generation. Vitrinite reflectance measurements of about $0.47 \% \mathrm{Rmo}$ in coals of the same age in the Lusulu area to the east of Wankie are not, however, high enough to indicate substantial

generation of any hydrocarbons. Thus, unlike the Wankie rocks, these coals have neither been deeply buried nor thermally affected by the basalt flows.

In summary, the Karoo sedimentary sequence of the midZambezi Valley contains some excellent reservoir rocks. The massive, fine clastic sediments of the Madumabisa Formation, particularly its lower and the upper portions, provides the main eap rock. The long lasting tectonic activities have created a dense grid of faults and uplifted, downthrown and tilted blocks, which collectively provide excellent migration paths towards the structural trap. However, they may also break the seals, an aspect that must be taken into account when evaluating tectonic evolution of the area following the first accumulation of hydrocarbons. It is likely that gas may have been trapped in fault closures and stratigraphic traps in the arenaceous sediments.

\section{The East-West Portion of the Zambezi Rift}

The east-west trending part of the Zambezi rift (Fig. 2) is much less geologically known. However, aeromagnetic, geo-electrical, gravity and geological surveys carried out in recent years have provided some new data on the structural setting of this area. In general, that part of the Zambezi Valley that trends NE-SW appears to be related to the group of similarly trending rifts that include the Luangwa and Luano valleys and the Kafue trough in Zambia (Fig. 9), and the Okavango area of Botswana. They also have asymmetric profiles with the steeper flank and the main boundary faults on their northwestern side.

The east-west portion of the Zambezi Valley seems part of a different tectonic setting. It is also asymmetric in shape, but with its steeper slope to the south, where a prominent escarpment may represent a "fundamental east-trending suture in the earth's crust" (Broderick, 1983). Aeromagnetic surveys indicate two magnetic basement levels (Bosum, 1985), the upper of which probably marks the Karoo basalts.

From the petroleum perspective, the lower level is of great importance because it could mark the top of the basement. It is on average about $3,000-\mathrm{m}$ deep, descending to a maximum of around $5,000 \mathrm{~m}$ in the area west of the Chewore horst (see Fig. 2). East of this structural feature, the same

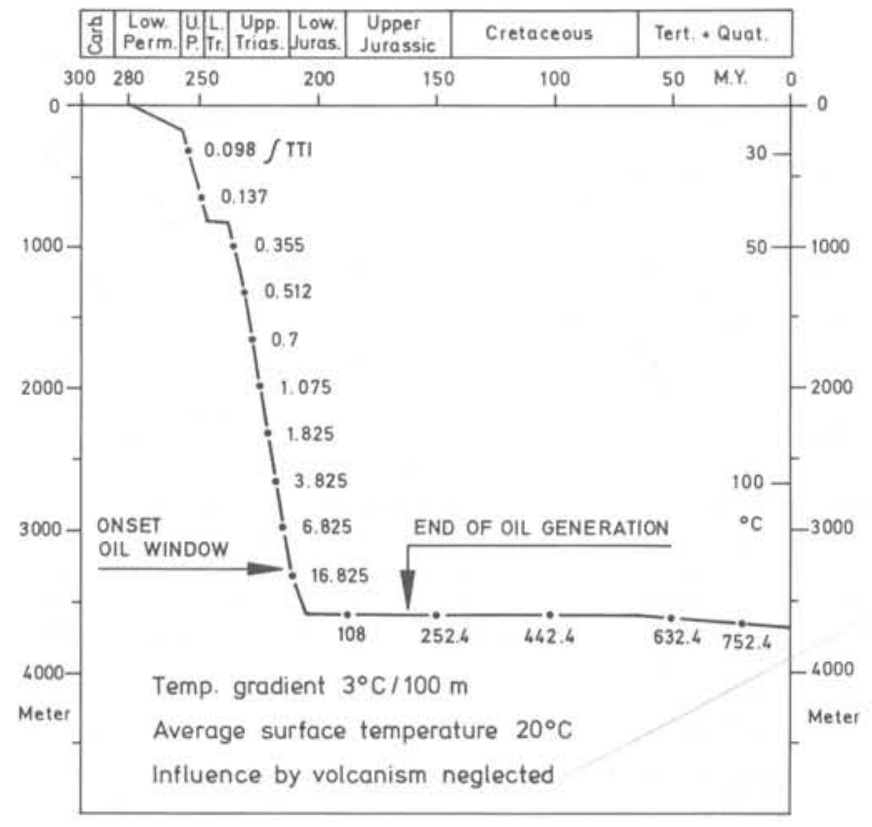

Figure 8: Maturity calculation using the base of the Gwembe Coal Formation as the reference horizon. SW Gwembe district. 
magnetic horizon dips from 6,000 down to $10,000 \mathrm{~m}$, suggesting a thickening of the overlying sedimentary sequence, and particularly the Upper Karoo, in an easterly direction. The upper magnetic level also extends down to $2,000 \mathrm{~m}$, a situation that could be at least partially explained by the presence of up to $1,000 \mathrm{~m}$ of Cretaceous sediments overlying the Karoo sequence (Broderick, 1983).

A final conclusion regarding the hydrocarbon potential here is not yet possible, but it can be assumed that the area west of the Chewore horst contains a similar sequence (with source and reservoir rocks) to that of the mid-Zambezi Valley. The traps should also be much the same, and the source rocks could have reached more or less the same degree of maturity. East of the Chewore horst, further studies are required before the structural setting, thickness and facies of the sedimentary sequences are understood. The magnetotelluric survey planned by BGR in this area should provide new data to assist in the reconstruction of the structural and depositional development here.

\section{Karoo Basins of Zambia}

The Luangwa Valley of northeastern Zambia, with a length of about $600 \mathrm{~km}$ and a width of $100 \mathrm{~km}$ has a similar structural and depositional development to the mid-Zambezi Valley (Fig. 9). At the base of the Karoo sequence in the upper Luangwa Valley lies the Luwumbu Coal, a timeequivalent of the Gwembe Formation (Drysdall and Weller, 1966). This contains in addition to coal seams and carbonaceous mudstones, prominent coarse-grained arenaceous sediments with carbonaceous matter and pebbles of crystalline rocks. Such a composition indicates spasmodic tectonic movements of a greater intensity than those occurring in the Zambezi area at the same time. The discontinuous subsidence of this basin continued into Lower Beaufort times.

The Luwumbu Formation provides the only source rock assemblage in the Luangwa Valley. Its type III kerogen coals and carbonaceous mudstones could provide gas only. Suitable reservoir rocks are the arenaceous, partially pebbly horizons in the Luwumbu Formation and in the lower Madumabisa Formation. The Escarpment Grit and the Upper Grit Formation of Upper $\mathrm{Karoo}$ age cannot be regarded as potential reservoirs because they are not overlain by extended cap-rock sequences.

Since its sedimentary sequence has a similar thickness and burial history as the Karoo sediments of the mid-Zambezi Valley, maturity calculations for the Luangwa rift provide more or less the same results. Using thermal gradients of $2.5^{\circ} \mathrm{C}, 3.0^{\circ} \mathrm{C}$, and $3.5^{\circ} \mathrm{C}$ per $100 \mathrm{~m}$, the source rocks would now be in the maturity range between the oil window and the peak-zone of dry gas generation. Similar results were obtained from maturity calculations on the "Coal Measures" of the Lukasashi and Luano valleys.

In the Kafue trough, Karoo sequences are poorly exposed, but data from a few boreholes suggest that this basin passed through a similar development as the Zambezi rift, from which it is separated by the crystalline rocks of the Choma-Kalomo ridge. The regional geological setting indicates that the Kafue trough plunges southwestwards, truncating the southernmost portion of the Barotse basin (Fig. 9). Boreholes close to the southern margin of the Kafue Flats indicate the presence of Lower Karoo sediments underlying the alluvial plain, and a hole drilled at Nega Nega penetrated a typical Ecca sequence composed of coals, dark shales and sandstones (Drysdall and Weller, 1966). Another well, just $5 \mathrm{~km}$ to the northeast, intersected a Madumabisa Mudstone succession about $500 \mathrm{~m}$ thick. The most promising area for further hydrocarbon exploration appears to be that strip where the plunging Kafue trough intersects into the southern Barotse basin, to the southwest of Mulobezi (Fig. 9). The basement here may be fairly deep and consequently covered by thick sedimentary sequences.

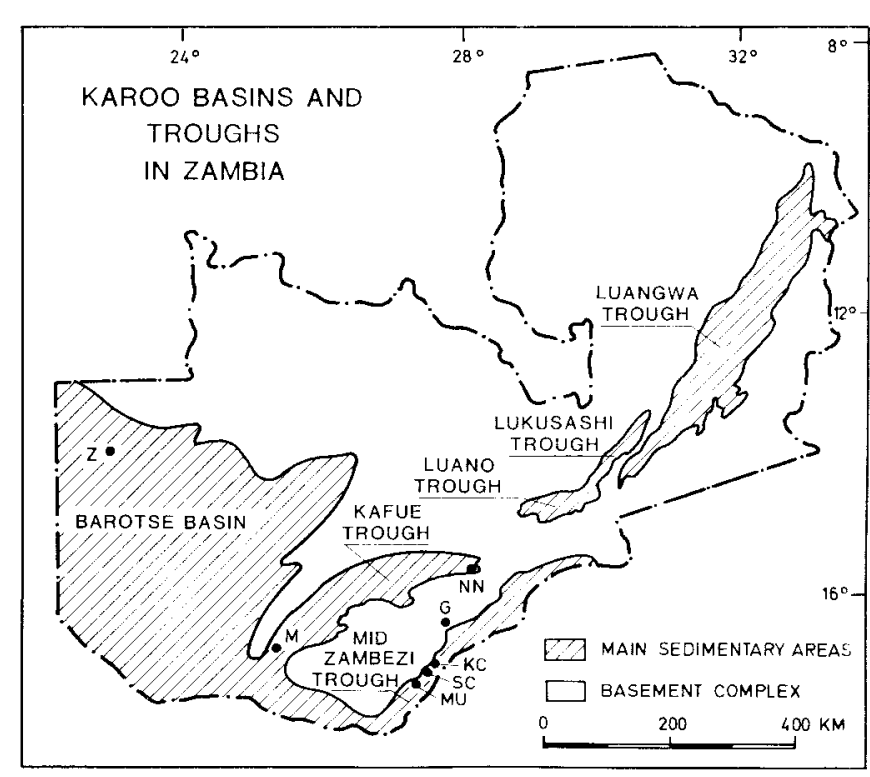

Figure 9: Distribution of Karoo sediments in Zambia. G - Gwembe, KC - Kandabwe coal field, $M$ Mulobezi, MU - Mulungwa area, NN - Nega Nega, SC - Siankondobo coal field, Z - Zambezi

The Barotse basin in the western Zambia offers two contrasts with the other Karoo basins discussed. First it is neither a rift nor a rifted syncline, but a bowl-shaped, block-faulted basin with gently dipping flanks. Second, the Barotse basin offers the chance for an oil-prone source rock. Money (1972) has described a sedimentary sequence of pre-Karoo age that penetrated a borehole near Likupekupe. This is the Likupekupe Formation, a two-m thick alternation of arkosic layers and blue-grey mudstones containing dark greyish mudflakes and fossils of a tentative OrdovicianSilurian age (Utting and Vavrdova, 1972). This sequence lies between the granitic basement and the base of Lower Karoo and has been interpreted as deposited in a marine environment. Similar deposits are known from Namibia and South Africa, and there is a good chance of encountering thicker sequences of this rock-type in other parts of the Barotse basin. Furthermore, these sediments raise the hope for a source rock containing the type II kerogen, which generates predominantly oil.

According to Money (1972), the Karoo sequence that overlies these marine sediments was deposited in a miogeosynclinal environment and comprises a $1,000-\mathrm{m}$ thick suceession, which easily fits into the framework of the classic

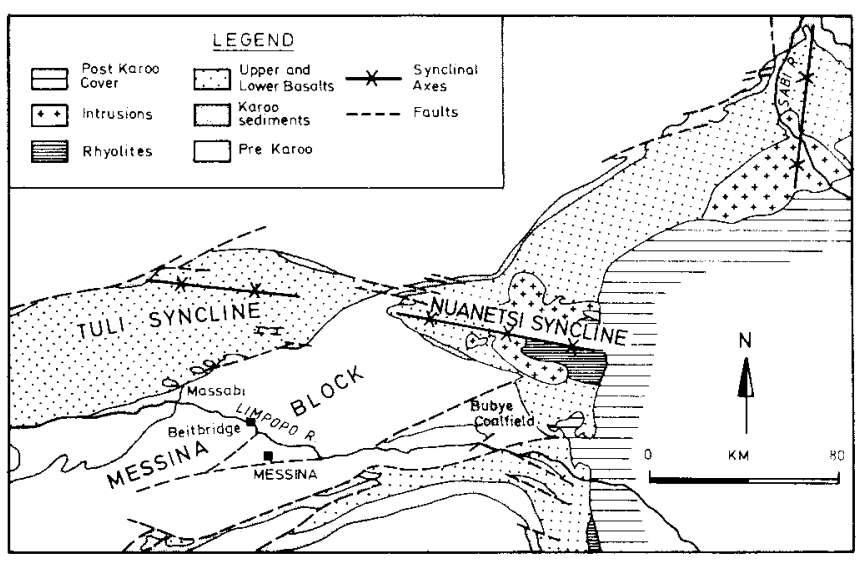

Figure 10: Geological map of the Limpopo area (modified after Cox, in Clifford and Gass, 1970). 
Karoo stratigraphy. Considering the depth of top basement, the structural setting, the distribution of basalts and the facies of source rocks, the block-faulted area around the town of Zambezi at the upper course of the Zambezi River seems very suitable for hydrocarbon exploration.

\section{The Karoo in Zimbabwe}

From the petroleum perspective the Sabi, Nuanetsi and Tuli synclinal trends at the southeastern corner of Zimbabwe (Figs. 2,10) appear to be less prospective. As in the Wankie and Gwai areas, the relatively thin Karoo sequence is overlain by a thick (to $7,620 \mathrm{~m}$ ) volcanic succession, the Nuanetsi lavas consisting of basalts and rhyolites, which represent a series of repeated tectonic and volcanic events (Bristow and Saggerson, 1983). The thermal influence of these mighty lava flows created unfavourable conditions for the generation and accumulation of hydrocarbons, and similar conditions have prevailed in the Tuli and in the Sabi synclines.

\section{Karoo Basins of Botswana}

In Botswana, the basement is almost entirely covered by sedimentary rocks whose structural setting has been unveiled step by step during the last decade. Still unknown, however, is the composition of the sequences that overly the basement in areas where the magnetic basement drops to a depth of $15,000 \mathrm{~m}$. Figure 11 shows the three main depressional features in Botswana, the Passarge, Nosop and Neojane basins, which are controlled by old plate boundaries on one side and by lineaments following older orogenic trends on the other.

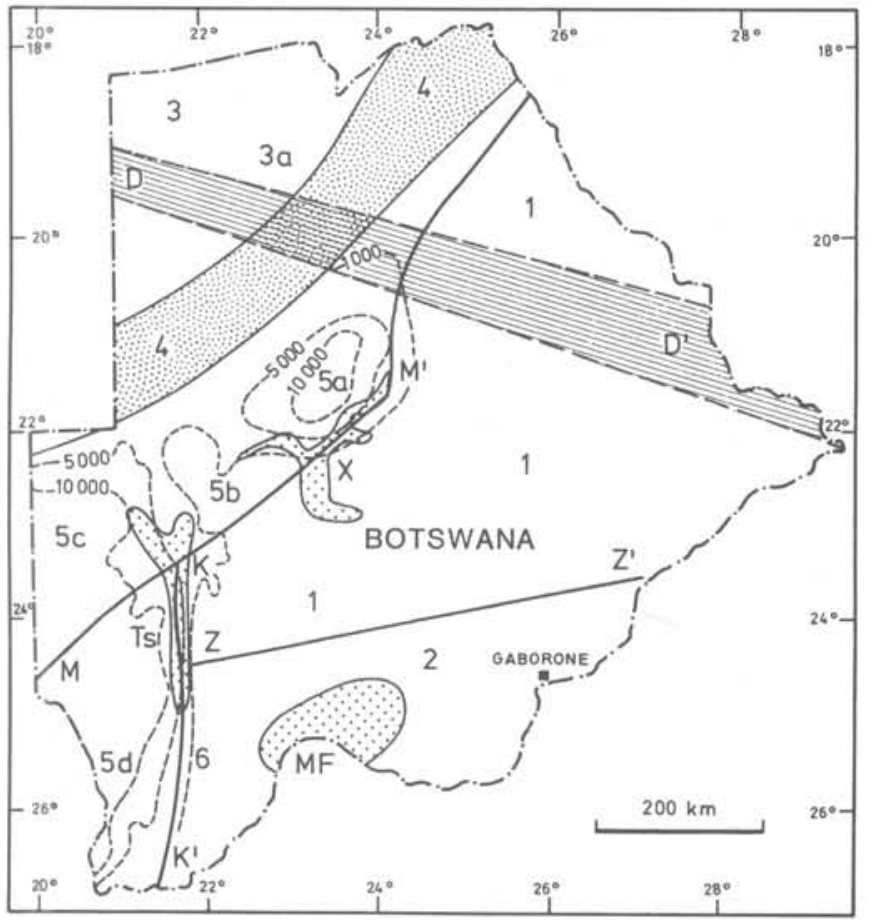

Figure 11: Major divisions of the pre-Karoo basement (modified after Reeves, 1978). I - East and central basement; 2 - Southern basement; 3 Northwest basement; $3 a$ - Okavango delta; 4 - GhanziChobe fold belt; $5 a$ - Passarge basin; $5 b$ - Okwa basement; $5 c$ - Ncojane basin; $5 d$ - Nosop basin; 6 Kheis belt; $M-M$ ' - Makgadikgadi line; K-K' - Kalahari line; $\mathrm{Z}-\mathrm{Z}^{\prime}$ - Zoetfontein fault; $D-D^{\prime}$ - Main dike swarm; $X$ - Xade complex; Ts - Tshane complex; MF - Molopo Farms complex. Dashed lines are basement contours in metres below surface.
Some information can be obtained from the Vreda 1 well drilled on Namibian territory some $75 \mathrm{~km}$ west of the Botswana border at a latitude of about $24^{\circ} 50^{\prime} \mathrm{S}$. This reached a depth of $1829 \mathrm{~m}$, penetrating Kalahari beds, Lower Karoo, Fish River Series and dolerite, but Upper Karoo sediments were not encountered. The base of Lower Karoo was intersected at a depth of $886 \mathrm{~m}$, and Dwyka tillites overlie here arenaceous sediments of the Fish River Series (Wilson, 1964).

According to Germs (1972) and Tankard et al. (1982), the Fish River sequence is composed mainly of brown and green sandy siltstones and red-brown sandstones in a molasse-type succession of Cambrian age. The sequence could be contemporaneous with the uppermost Kundelungu sediments and the lower Likupekupe Formation of Zambia, which seem to mark the last depositional phase of the Pan-African orogeny. The uppermost Likupekupe sediments, as seen earlier, are of Ordovician age. There is a chance, that the Fish River sequence, which may have been deposited in a late geosynclinal environment, might contain fine clastics with enough organic matter to act as a source rock for oil generation. Thus, in all three Botswanan basins there is potential for both oil and gas source rocks.

\section{Conclusions}

All the basins and troughs reviewed in this study have potential source rocks. Most probably contain type III kerogen, characteristic of gas-prone source rocks. The deep basins in Botswana and the Barotse basin of Zambia may also have pre-Karoo marine rocks with type II kerogen and oil sources. Most of the rift deposits have already passed through the oil window and are presently in the stage of wet gas generation. Favourable trap conditions are present in the form of normal fault closures, reverse fault closures and up-dip pinchouts, but tectonic movements lasting from middle Mesozoic to Recent could have destroyed already filled traps. Water flushing along the numerous faults is one of the main barriers to the accumulation of hydrocarbons. Unfavourable conditions also arise from the presence of dolerite intrusions and lava flows. Additional geophysical investigations such as magnetotelluric and seismic surveys are necessary to obtain more data regarding the basin geometry, the structural setting and the depositional history.

\section{Acknowledgements}

The author thanks the President of BGR (the Federal Institute for Geosciences and Natural Resources, F.R.G.), Prof. Dr. M. Kürsten, for permission to publish the results of this 1984-1985 study, which was financially supported by the Federal Ministry for Economic Cooperation in Bonn. Special thanks are due to the directors and many geologists of the Geological Surveys in Zimbabwe, Botswana and Zambia for their assistance during data collection in Harare, Lobatse and Lusaka. The author is indebted to Dr. K. Hiller, for stimulating ideas, suggesting improvements and the critical reading of the typescript. Thanks are due to Dr. S. Paulsen, BGR, for promoting the study and for providing technical support. Mrs. B. Peisker is thanked for typing the manuseript and for draughting the illustrations.

Dr. K.-U. Reimann has been with the BGR (P.O. Box 510153, D-3000 Hannover 51, F.R.G.) since 1973. For ten years he worked in Burma and in Bangladesh as a stratigrapher and petroleum geologist with West German technical missions. More recently he has reviewed the hydrocarbon prospects in Southern, Central and East Africa.

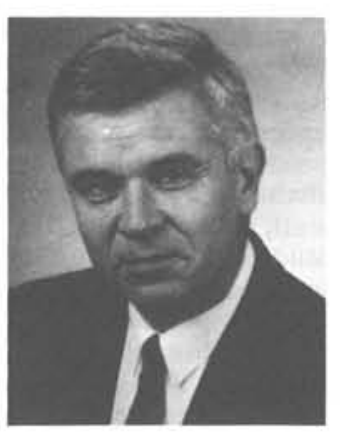




\section{References}

Bosum, W., 1985. Interpretation of the Aeromagnetic survey of the Zambezi Valley/Zimbabwe. Unpublished BGR report, Archives no. $97681,18 \mathrm{p}$.

Bristow, J.W. and Saggerson, E.P., 1983. A Review of Karoo Vulcanicity in Southern Africa. Bulletin Volcanologique, vol. 46, no. 2, p. 135-159.

Broderick, T.J., 1983. A geological interpretation across a portion of the mid-Zambezi valley lying between the Mkanga and Hunyani rivers, Guruve District. Annals of the Zimbabwe Geological Survey, vol. IX, p. 59-79.

Clifford, T.N. and Gass, I.G. (eds.), 1970. African magmatism and tectonies. Hafner Publishing Company, Darien, Connecticutt.

Coates, J.N.M. et al., 1979. The Kalatravers. One Report. Botswana Geological Survey, Bulletin Series, Bulletin 21, $408 \mathrm{p}$.

Denman, P.D. and Money, N.J., 1968. The coal resources of the Zambezi valley, $V$, Siankondobo - the north-eastern area, Preliminary report. Zambia Geological Survey, Economic Report no. 23, vol. 1, 14p.

Drysdall, A.R. et al., 1967. The coal resources of the Zambezi valley, IV, Siankondobo - the Izuma basin. Zambia Geological Survey, Economic Report no. 16, vol. 1, 28p.

Drysdall, A.R. and Weller, R.K., 1966. Karoo sedimentation in Northern Rhodesia (with discussion). Transactions of the Geological Society of South Africa, vol. LXIX, p. 39-69.

Germs, G.J.B., 1972. The stratigraphy and paleontology of the Lower Nama Group, South West Africa. Cape Town University, Department of Geology, Precambrian Research Unit, Bulletin 12, 250p.

Mallick, D.I.J. et al., 1981. A geological interpretation of Landsat imagery and air photography of Boswana. Institute of Geological Sciences, Overseas Geology and Mineral Resources, Number 56, 35p.

Money, N.J., 1981. Hydrocarbon potential of Zambia. Zambia Geological Survey, Occasional Paper no. 106, 15p.

Money, N.J., 1972. An outline of the geology of Western Zambia. Records of the Geological Survey, Zambia, vol. 12, p. 103-123.

Paroda, H., 1983. Geodynamic Model for the Geosynclinal Development of the Damara Orogen, Namibia, South West Africa. In: Martin, H. and Eder, F.W., 1983. Intracontinental Fold Belts. Springer Verlag, Berlin, p. 503-541.

Pretorius, D.A., 1979. The aeromagnetic delineation of the distribution patterns of Karoo volcanics in Botswana and consequent implications for the tectonics of the subcontinent. Botswana Geological Survey, Bulletin Series, Bulletin 22 , p. $93-139$.

Reeves, C.V., 1978. Interpretation of the reconnaissance aeromagnetic survey of Botswana. Final Report, Terra Surveys Ltd., 199p.

Reeves, C.V. and Hutchins, D.G., 1976. The national gravity Survey of Botswana, 1972-73. Botswana Geological Survey, Bulletin Series, Bulletin 5, 45p.

Saviaro, K., 1979. Preliminary analysis of the airborne magnetic surveys in Zambia. Botswana Geological Survey, Bulletin Series, Bulletin 22, p. 159-182.

Smith, R.A., 1984. The lithostratigraphy of the Karoo Supergroup in Botswana. Botswana Geological Survey, Bulletin Series, Bulletin 26, 239p.

Tankard, A.J. et al., 1982. Crustal evolution of Southern Africa. 3.8 billion years of earth history. Springer Verlag, New York, 523p.
Tavener-Smith, R., 1960. The Karoo System and coal resources of the Gwembe District, South-West Section, Northern Rhodesia Geological Survey, Bulletin no. 4, 84p.

Utting, J. and Vavrdova, M., 1972. Acritarchs and other microfossils from a borehole in Western Province. Records of the Geological Survey, Zambia, vol. 12, p. 125-129.

Waples, D.W., 1980. Time and temperature in petroleum formation application of Lopatin's method to petroleum exploration. American Association of Petroleum Geologists, Bulletin vol. 64 , no. 6, p. 916-926.

Watson, R.L.A., 1960. The geology and coal resources of the country around Wankie, Southern Rhodesia. Southern Rhodesia Geological Survey, Bulletin no. 48, 57p.

Wilson, E.J., 1964. Core description, Vreda 281 no. 1 (Stratigraphic test). Artnell Exploration Company, 36p., Windhoek.

Zhou, P.P., 1984. Zimbabwe. Major geophysical projects carried out in 1983. Annals of the Zimbabwe Geological Survey, volume IX (1983), p. 108-125.

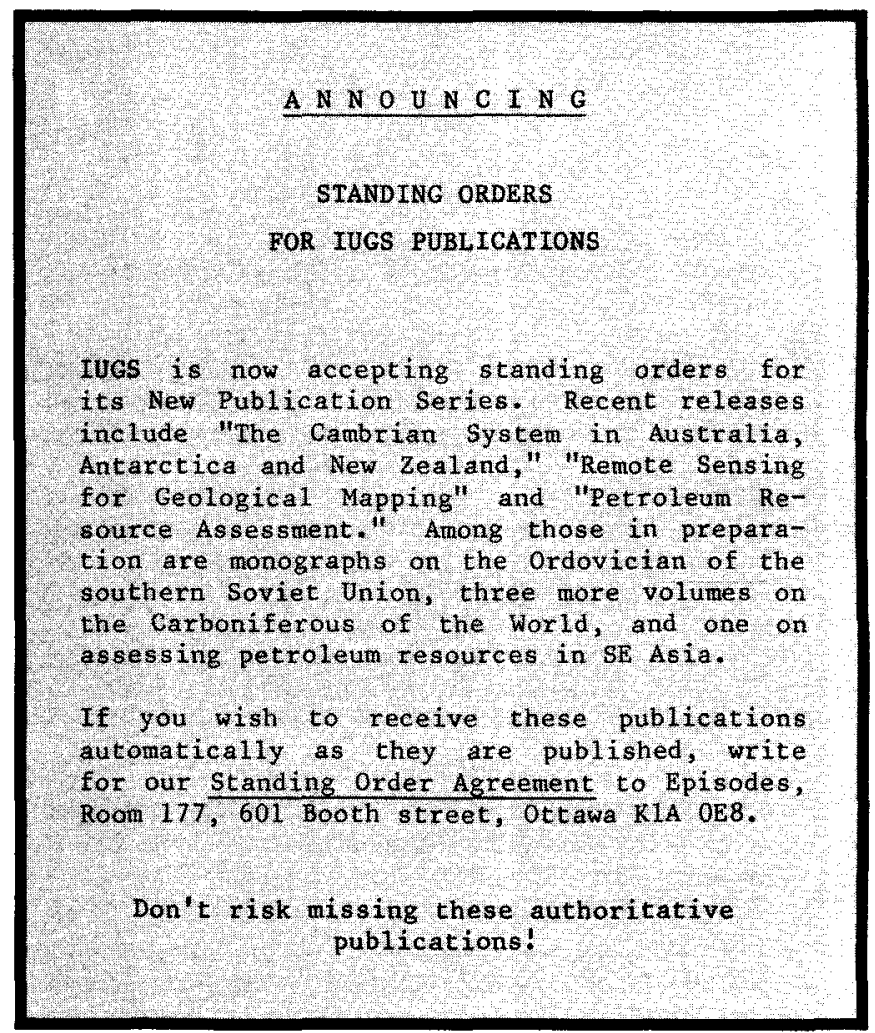




\section{Attention Mineral Explorationists}

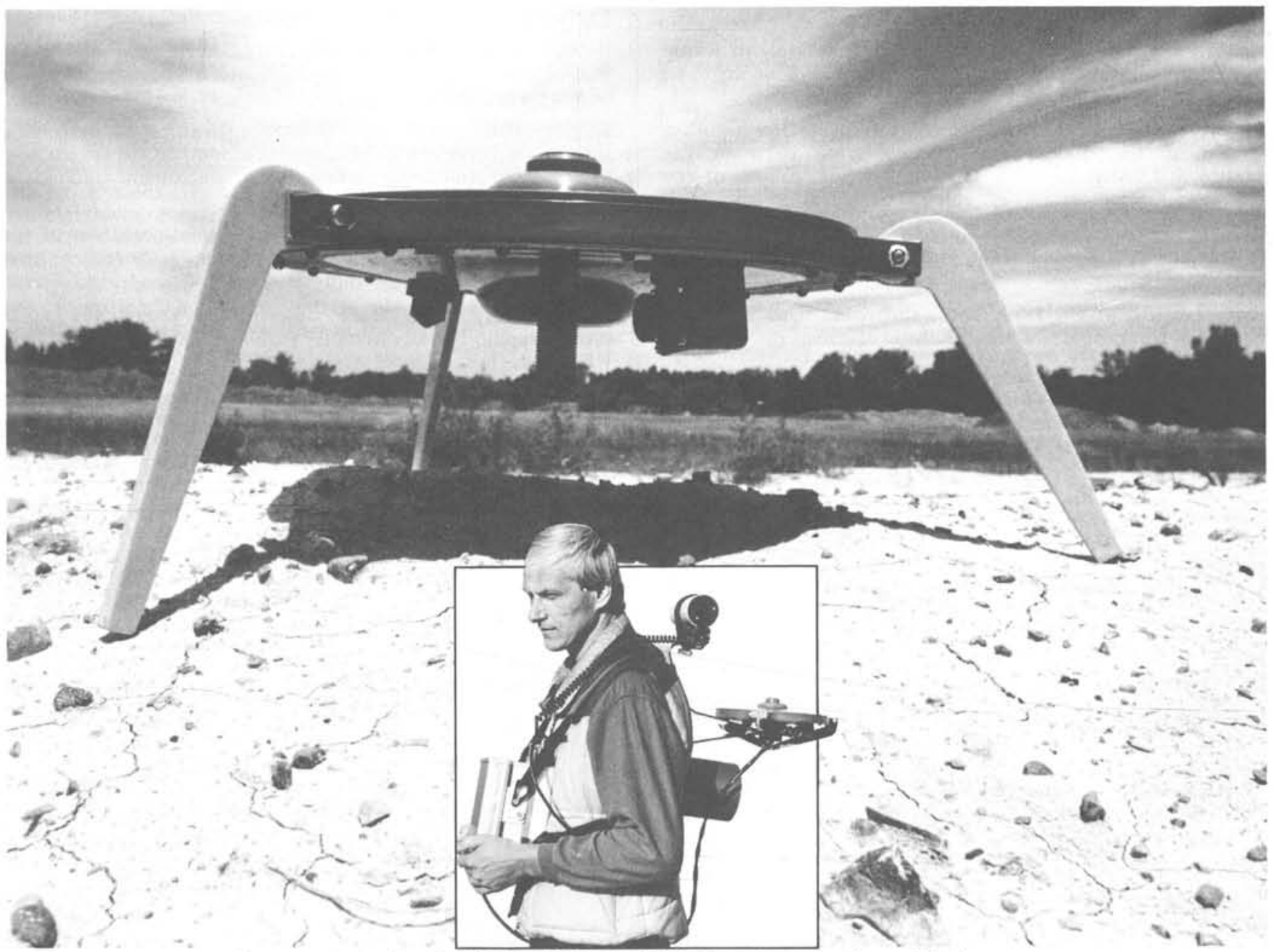

One operator, using the EM-4 coil with an IGS-2 Console, magnetic and VLF sensors can efficiently record up to 12 different geophysical parameters in solid-state memory.

\section{The new Scintrex EM-4 is here to improve your ground electromagnetic surveys}

This unique EM receive coil, $25 \mathrm{~cm}$ in diameter and weighing only $1.8 \mathrm{~kg}$, is the third sensor now available for the Scintrex IGS Integrated Portable Geophysical System. It complements magnetic and VLF sensors which, with the IGS-2 System Control Console, are already proving that multiple parameter surveys save time and money in ground geophysical surveying.

The advantages of the programmable, microprocessorbased IGS instrumentation are numerous. They include automatic recording of coordinates, time and data in solid-state memory and outputs to printers, modems or microcomputers to list, plot, transmit, store or process data.
An IGS-2/EM-4 Receiver can be used with either moving or fixed source Scintrex transmitters for rapid or deeply penetrating surveys. Either GENIE amplitude ratio or standard Slingram measurements can be made. The wide frequency range, signal/noise enhancement, simplicity of operation, complete interpretation procedures and numerous other features place the EM-4 in a class by itself.

To find out more about how our new EM-4 coil can improve your EM surveys, contact Scintrex at 222 Snidercroft Road, Concord, Ontario, Canada L4K 1B5, telephone (416) 669-2280, telex 06-964570.

\section{SCINTAEX}

